\title{
低魚毒性含ケイ素ピレスロイドの合成ならびに殺虫活性
}

\author{
大塚俊一 \\ 塩野義製薬株式会社油日ラボラトリーズ
}

\section{Synthesis and Insecticidal Activity of Silicon-containing Pyrethroids with Low Fish Toxicity}

\author{
Toshikazu OHTSUKA \\ Aburahi Laboratories, Shionogi Research Laboratories, Shionogi \& Co., Ltd., \\ Koka-cho, Koka-gun, Shiga 520-34, Japan
}

In the course of study on new pyrethroids, it was found that organosilicon compounds substituted with silicon atom at the quaternary carbon atom of ethofenprox were showed pyrethroidal insectactivity. Among them dimethyl(4-ethoxyphenyl)silylmethyl-3-phenoxybenzyl ether (SSI-116) was selected as the most potent candidate, which has broad-spectrum insectactivity, extremely low fish toxicity and low mammalian toxicity. The comparison between SSI-116 and ethofenprox in various biological activity to insects suggested that SSI116 acted as a bioisostere of ethofenprox against insects and was classified to type I pyrethroids. But in fish toxicity the large difference between them was observed, that is the $\mathrm{LC}_{50}$ value for carp of SSI-116 and ethofenprox were $>562 \mathrm{ppm}$ and $5.0 \mathrm{ppm}$, respectively. In the field trials SSI-116 was effective agent for control of pests in rice paddy field. The results sugges:ed that sila-substitution of known pesticides might be available method for future pesticicle development.

\section{はじめに}

合成ピレスロイド阂は, Schtchter らによりはじめて 開発が成功して以降1)，活性的にも，構造的にも，非常 に画期的な変化を遂げている殺虫剤である. 速効性で， 幅広い殺虫スペクトルを有しており，農業害虫の防除上 欠くことのできない剤である2)。しかし，毒性面に久点 があり，とくに高い魚毒性を有するため, 水田害虫の防 除には使用することができなかった，一方，水田用殺虫 剤の分野では, 有機りン系およびカーバメート系殺虫剂 に対するッマグロヨコバイおよびゥンカ類の抵抗性が問 題化し ${ }^{3)}$, さらに新たな水田管虫としてイネミズゾウム シが発生したため4)，低魚毒性のピレスロイド剤の開発 が切望されていた。

そんななか，1980 年代に入り三井東圧化学(株) が低
魚毒性で，ピレスロイド様活性を示すエーテル化合物 MTI-500（エトフェンプロックス）を見いだし，水田用 殺虫剂としての開発を検討していだ5).

同じ頃，医薬の分野では生理活性有機 ケイ素化合物 (シラファルマカ) の研究が盛んに行なわれており, 既 存剤の一部の炭素原子をケイ素原子に置換するケイ素置 換法 (sila-substitution) の有用性が報告されていた6). すなわち炭素原子をケイ素原子に置換したケイ素置換体 は, 両原子間の種々の性質の違いから, 合成, 活性およ び毒性の面で改良されることである7).

そこで，筆者らは MTI-500 にこのケイ素置換法を試 み，新規な含ケイ素系殺虫剤を見いだすことおよび農薬 の分野におけるケイ素置換法の有用性の有無を調べるこ とを目的に，本研究を開始した。

その結果，低魚毒性で，畕場試験においても水田害虫 
防除に有効な SSI-116 を見いだすに至った。以下に， その研究概要について述べる.

\section{SSI-116 類緣体の合成}

MTI-500 (エトフェンプロックス) の 4 級炭素原子を ケイ素原子で置換した SSI-116 類縁体の合成を行なっ た (Fig. 1). 最終段階でエーテル結合を形成して目的物 を得ることにした (Fig. 2). まず A 法について，クロ ロメチルジメチルフェニルシランと 3-フェノキシベン ジルアルコールを用いて，置換反応を行なったが反応は

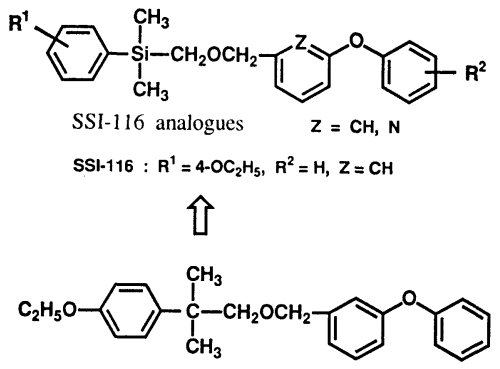

MTI-500, ethofenprox

Fig. 1 Sila-substitution of MTI-500 to SSI-116 analogues.
進行しなかった。しかし，シリルメタノール体を用いる B 法では，スムーズに反応が起こり目的の SSI-116 類 縁体を得ることができた。そこで，既知の方法を用いて， ジメチル (置換フェニル) シリルメタノール体と 3-(置 換フェノキシ)ベンジルブロミド体および 6-(フェノキ シ）2-ピリジルメチルブロミドを合成した $(\text { Fig. 2 })^{8,9)}$. それらの 1,3-ジメチル-2-イミダゾリジノン溶液中に, tret ブトキシカリウムを加えることにより，高収率で SSI-116 類縁体を得た (Fig. 2). しかしこれらの合成に おいて，シリルメタノール体がその炭素化合物の場合と 若干異なる化学的挙動を示すことを見いだした。すなわ ち, ジメチルフェニルシリルメタノールは, 1,3-ジメチ ル-2-イミダゾリジノン溶液中, tret ブトキシカリウム 存在下では不安定で $--5 \sim 0{ }^{\circ} \mathrm{C}, 1$ 時間で $80 \%$ ほど分 解することがわかった．したがって，含ケイ素農薬を合 成する際は，反応性および安定性に十分留意することが 大切である。

次に, SSI-116 類縁体の生物活性について検討した.

\section{SSI-116 類緑体の生物活性}

\section{1. 殺 虫活 性}

今回合成した SSI-116 類縁体のハスモンヨトウ (Spodopteva litura)，コナガ (Plutella xylostella) およ<smiles>C[Si](C)(CC=Cc1cccc(Oc2ccccc2)c1)c1cccc([Tl])c1</smiles>
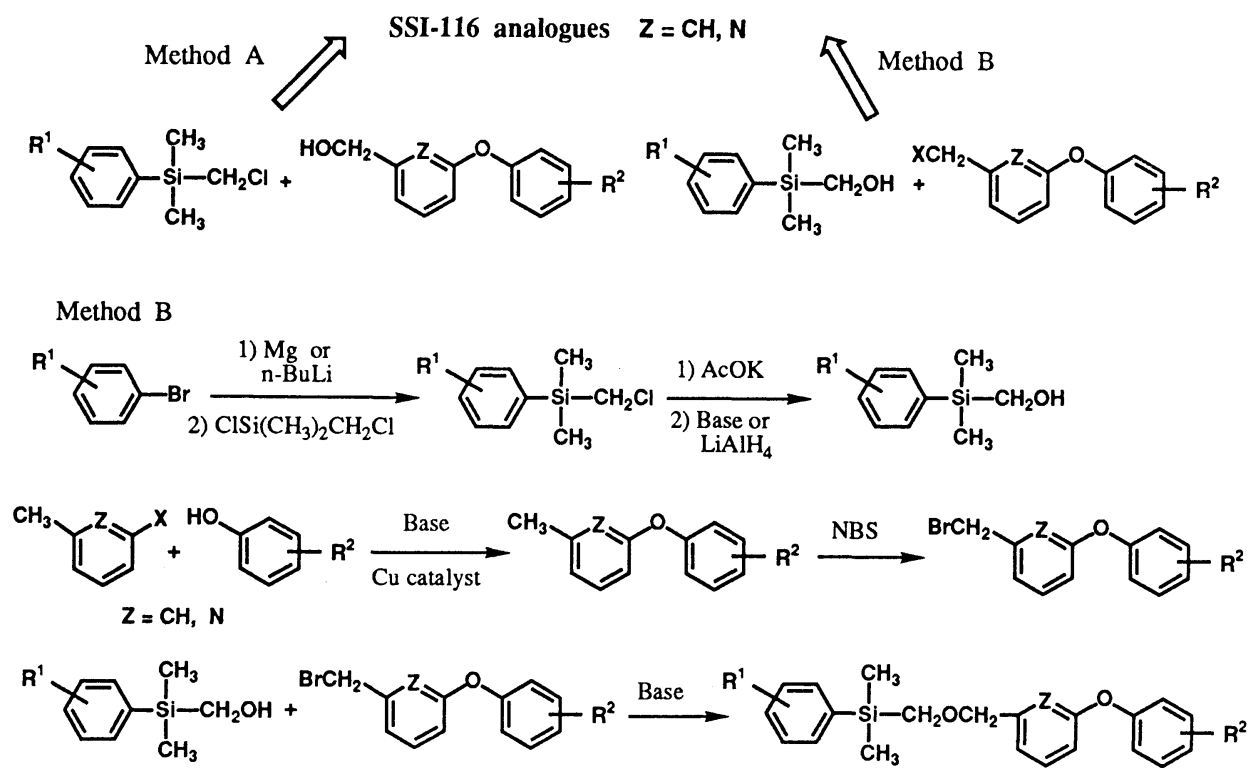

Fig. 2 Synthesis of SSI-116 analogues. 
びッマグロヨコバイ (Nephotettix cincticeps) について 構造と殺虫活性の相関を調べた (Table 1〜3). まずべ ンゼン環の置換基 (エトキシ基) の置換位置については, 4 位が最も活性が高く，3 位，2 位となるごとに極端に 活性は低下した (Table 1). 次に, ジメチル (4-置換フェ ニル) シリルメチル 3-(置換フェノキシ)ベンジルェーテ ル体について調ベた (Table 2). ベンゼン環の 4 位の置 換基 $\left(\mathrm{R}^{1}\right)$ については，エトキシ基の酸素原子をイオウ

Talle 1 Effect of sulstitution on lenzene ring $\left(\mathrm{R}^{1}\right)$ on the insecticidal activity.

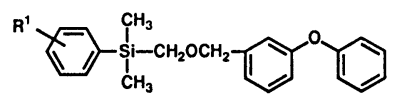

\begin{tabular}{|c|c|c|c|c|c|}
\hline \multirow{4}{*}{$\mathrm{R}^{1}$} & \multicolumn{5}{|c|}{ Mortality $(\%)$ at $48 \mathrm{hr}$ after reatment $\left.^{2}\right)$} \\
\hline & \multicolumn{2}{|c|}{ S. litura } & \multirow{3}{*}{ 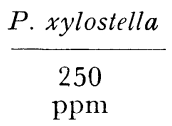 } & \multicolumn{2}{|c|}{ N. cincticips } \\
\hline & 1000 & 250 & & 1000 & 250 \\
\hline & ppm & ppm & & ppm & ppm \\
\hline $2-\mathrm{OC}_{2} \mathrm{H}_{5}$ & 5 & NT & NT & 0 & NT \\
\hline $3-\mathrm{OC}_{2} \mathrm{H}_{5}$ & 75 & NT & NT & 33 & NT \\
\hline $4-\mathrm{OC}_{2} \mathrm{H}_{5}$ & 100 & 100 & 95 & 100 & 47 \\
\hline
\end{tabular}

a) $\mathrm{NT}=$ not tested.
原子に換えエチルチオ基にすると活性は低下した．しか しながら，その他のアルコキシ基，アルキル基および八 ロゲン原子についてはそれほど大きな違いは認められな かった. そして, 無置換の場合も, かなり高い活性を示 した. 次に，4-エトキシフェニルに固定して，3-フェ ノキシの置換基 $\left(\mathrm{R}^{2}\right)$ について調べたところ，4-フルオ 口体が無置換体とほぼ同等の活性を示すことがわかっ た. 最後に, ジメチル (4-置換フェニル)シリルメチルー 6-フェノキシー2-ピリジルメチルエーテル体について調 ベたところ, 無置換体の場合を除いて, 先ほどと同様,

置換基 $\left(\mathrm{R}^{1}\right)$ で活性に大きな違いは認められなかった (Table 3). また， ピリジルエーテル体はベンジルエー テル体と同等の活性を示した. 以上, あまり明瞭な相関 関係は得られなかったが，置換基 $\left(\mathrm{R}^{1}\right)$ はエトキシ基ぐ らいまでの大きさで，4位に置換し，置換基 $\left(\mathrm{R}^{2}\right)$ は水 素原子 (すなわち無置換) である SSI-116 類縁体が， 高い殺虫活性を示す傾向にあった。

\section{2. 魚 性}

殺虫活性の高かった SSI-116 類縁体についてヒメダ 力 (Oryzias latipes) を用い農薬取締法に基づく標準試 験法に準拠して，急性毒性試験を実施した（Table 4). 供試したヒメダカの平均全長および平均体重は, 2.20

Table 2 Effect of sals itution on kenzene ring $\left(R^{1}\right)$ and phenoxy group $\left(R^{2}\right)$ on the insecticidal activity.

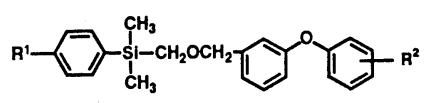

\begin{tabular}{|c|c|c|c|c|c|c|}
\hline \multirow{3}{*}{$R^{1}$} & \multirow{3}{*}{$\mathrm{R}^{2}$} & \multicolumn{5}{|c|}{ Mortality $(\%)$ at $48 \mathrm{hr}$ after treatment $\left.{ }^{\mathrm{a}}\right)$} \\
\hline & & \multicolumn{2}{|c|}{ S. litura } & \multirow{2}{*}{$\frac{P . x y l o s t e l l a}{250 \mathrm{ppm}}$} & \multicolumn{2}{|c|}{ N. cincticeps } \\
\hline & & $1000 \mathrm{ppm}$ & $250 \mathrm{ppm}$ & & $1000 \mathrm{ppm}$ & $250 \mathrm{ppm}$ \\
\hline $\mathrm{H}$ & $\mathrm{H}$ & 100 & 20 & 80 & 100 & 76 \\
\hline $4-\mathrm{Cl}$ & $\mathrm{H}$ & 100 & 45 & 75 & 100 & 47 \\
\hline $4-F$ & $\mathrm{H}$ & 100 & 50 & 55 & 77 & NT \\
\hline 4- $\mathrm{CH}_{3}$ & $\mathrm{H}$ & 100 & 5 & 90 & 100 & 14 \\
\hline $4-\mathrm{OCH}_{3}$ & $\mathrm{H}$ & 100 & 10 & 65 & 100 & 20 \\
\hline $4-\mathrm{OCHF}_{2}$ & $\mathrm{H}$ & 100 & 100 & 100 & 100 & 10 \\
\hline $4-\mathrm{OC}_{2} \mathrm{H}_{5}$ & $\mathrm{H}$ & 100 & 100 & 95 & 100 & 47 \\
\hline $4-\mathrm{OCH}\left(\mathrm{CH}_{3}\right)_{2}$ & $\mathrm{H}$ & 100 & 80 & 100 & 100 & 16 \\
\hline $4-\mathrm{SC}_{2} \mathrm{H}_{5}$ & $\mathrm{H}$ & 95 & 0 & 60 & 92 & 0 \\
\hline $4-\mathrm{OC}_{2} \mathrm{H}_{5}$ & $2-\mathrm{Cl}$ & 40 & NT & NT & 39 & $\mathrm{NT}$ \\
\hline $4-\mathrm{OC}_{2} \mathrm{H}_{5}$ & $3-\mathrm{Cl}$ & 65 & NT & NT & 75 & NT \\
\hline $4-\mathrm{OC}_{2} \mathrm{H}_{5}$ & $4-\mathrm{Cl}$ & 40 & NT & NT & 73 & NT \\
\hline $4-\mathrm{OC}_{2} \mathrm{H}_{5}$ & $4-\mathrm{F}$ & 100 & 40 & 90 & 100 & 56 \\
\hline 4- $-\mathrm{OC}_{2} \mathrm{H}_{5}$ & $4-\mathrm{OCH}_{3}$ & 100 & 0 & 65 & 100 & 7 \\
\hline $4-\mathrm{OC}_{2} \mathrm{H}_{5}$ & $4-\mathrm{NO}_{2}$ & 15 & NT & N'T & 7 & NT \\
\hline
\end{tabular}

a) $\mathrm{NT}=$ not tested. 
Table 3 Effect of substitution on kenzene ring $\left(\mathrm{R}^{1}\right)$ on the insecticidal activity.

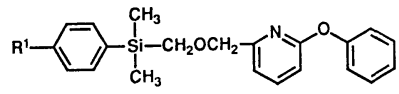

\begin{tabular}{|c|c|c|c|c|c|}
\hline \multirow{4}{*}{$\mathrm{R}^{1}$} & \multicolumn{5}{|c|}{ Mortality (\%) at $48 \mathrm{hr}$ after treatment $\left.{ }^{\mathrm{a}}\right)$} \\
\hline & \multicolumn{2}{|c|}{ S. litura } & \multirow{3}{*}{ 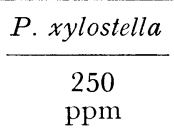 } & \multicolumn{2}{|c|}{ N. cincticeps } \\
\hline & 1000 & 250 & & 1000 & 250 \\
\hline & ppm & ppm & & ppm & ppm \\
\hline $\mathrm{H}$ & 45 & NT & 80 & 84 & NT \\
\hline $4-\mathrm{F}$ & 100 & 15 & 50 & 100 & 0 \\
\hline $4-\mathrm{Cl}$ & 100 & 75 & 85 & 94 & NT \\
\hline $4-\mathrm{CH}_{3}$ & 100 & 45 & 40 & 100 & 0 \\
\hline $4-\mathrm{OCH}_{3}$ & 100 & 0 & 60 & 100 & 0 \\
\hline $4-\mathrm{OC}_{2} \mathrm{H}_{5}$ & 100 & 0 & 70 & 100 & 50 \\
\hline $4-\mathrm{OCH}\left(\mathrm{CH}_{3}\right)_{2}$ & 100 & 35 & 100 & 100 & 0 \\
\hline 4-OCHF 2 & 100 & 100 & 80 & 100 & 0 \\
\hline
\end{tabular}

a) $\mathrm{NT}=$ not tested.

Table 4 Fish toxicity of SSI-116 analogues against $O$. latipes.

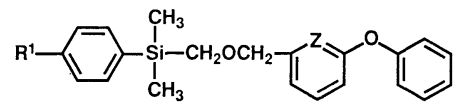

SSI-116 analogues

\begin{tabular}{|c|c|c|c|}
\hline $\mathrm{R}^{1}$ & $Z$ & TLm (ppm) & \\
\hline $\mathrm{H}$ & $\mathrm{CH}$ & $>178$ & \\
\hline $\mathrm{F}$ & $\mathrm{CH}$ & $>178$ & \\
\hline $\mathrm{Cl}$ & $\mathrm{CH}$ & $>178$ & \\
\hline $\mathrm{CH}_{3}$ & $\mathrm{CH}$ & $>178$ & \\
\hline $\mathrm{CH}_{3} \mathrm{O}$ & $\mathrm{CH}$ & $>178$ & \\
\hline $\mathrm{C}_{2} \mathrm{H}_{5} \mathrm{O}$ & $\mathrm{CH}$ & $>1000$ & SSI-116 \\
\hline$\left(\mathrm{CH}_{3}\right)_{2} \mathrm{CHO}$ & $\mathrm{CH}$ & 96 & \\
\hline $\mathrm{CHF}_{2} \mathrm{O}$ & $\mathrm{CH}$ & $>178$ & \\
\hline $\mathrm{C}_{2} \mathrm{H}_{5} \mathrm{O}$ & $\mathrm{N}$ & 0.28 & \\
\hline $\mathrm{CHF}_{2} \mathrm{O}$ & $\mathrm{N}$ & 0.11 & \\
\hline Permethrin & & 0.03 & \\
\hline
\end{tabular}

$\mathrm{cm}, 0.11 \mathrm{~g}$ であった. SSI-116 類縁体はすべて，代表 的ピレスロイドであるパーメスリンの文献值 ${ }^{10)}$ より毒 性は弱かった。なかでも 3-フェノキシベンジルエーテ ル体は，非常に毒性が低い化合物であった，その理由に 関する知見についてはコイに対する魚毒性とともにあと で述べる.

以上の殺虫活性試験と魚毒性試験の結果，ならびに合 成の容易さなどから，数種の 3-フェノキシベンジル エーテル体を選び，さらに試験を重ねた結果，最終的に SSI-116 (Fig. 1) を選抜した。その広い殺虫スペクト
Table 5 Insecticidal and miticidal activities of SSI-116 at 250 ppm.

\begin{tabular}{lc}
\hline \multicolumn{1}{c}{ Species } & Mortality $(\%)$ at $48 \mathrm{hr}$ \\
\hline S. litura (larvae) & 100 \\
P. xylostella (larvae) & 95 \\
A. orana (larvae) & 95 \\
M. persicae (larvae) & 50 \\
N. cincticeps (adults) & 47 \\
P. americana (larvae) & 100 \\
T. cinnabarius (adults) & 29 \\
C. chinensis (adults) & 100 \\
\hline
\end{tabular}

Table 6 Insecticidal activities of SSI-116 and ethofenprox topically applied to $N$. cincticeps, $L$. striatellus, $N$. lugens and S. furcifera.

\begin{tabular}{lccccc}
\hline \multirow{2}{*}{ Compound } & \multicolumn{4}{l}{$\mathrm{LD}_{50}(\mathrm{mg} / \mathrm{insect})$ at } & 24hr after treatment \\
\cline { 2 - 6 } & $\begin{array}{l}\text { N. } \\
\text { cincticeps }\end{array}$ & $\begin{array}{l}\text { L. } \\
\text { striatellus }\end{array}$ & $\begin{array}{l}\text { N. } \\
\text { lugens }\end{array}$ & $\begin{array}{l}\text { S. } \\
\text { furcifera }\end{array}$ \\
\hline SSI-116 & 52 & 2.9 & 8 & 1 & 7.5 \\
Ethofenprox & 1.9 & 13 & 3 & 4 & 1.2 \\
\hline
\end{tabular}

ルを示す (Table 5). なお SSI-116 は，構造的には， エトフェンプロックスの 4 級炭素原子をケイ素原子で置 換した化合物である. 次に，SSI-116の特徴づけをす るために，エトフェンプロックスとの生物学的および化 学的性質の比較検討を行なった。

\section{SSI-116 とエトフェンプロックスの比較}

\section{1. 局所施用法による殺虫活性}

SSI-116 は非常に魚毒性が低いので, 水出用の剂とし て適用可能である. そこで，先行剤であるエトフェンプ ロックスとの本質的な殺虫活性の違いを知る目的で，水 田の重要害虫である 4 種の半翅目害虫, ッマグロヨコバ イ, ヒメトビウンカ (Laodelphax striatellus), トビイロ ウンカ (Nilapavvata lugens), セジロウンカ (Sogatella furcifera) について, 局所施用法による殺虫活性を調べ た (Table 6). すなわち，アセトン薬液 $0.04 \mu \mathrm{l}$ をマイ クロシリンジにより供試虫の前部背板に局所施用した。 SSI-116 は，エトフェンプロックスよりやや劣る傾向 を示したが，いずれの虫に対しても LC 50 は小さな值を 示し，高い活性を認めた.

\section{2. 昆虫類および甲殼類に対する生理活性}

1）ワモンゴキブリに対するノックダウン活性

ワモンゴキブリ (Periplaneta americana) 雄成虫の腹 部に $32 \mathrm{nmol}$ のメタノール薬液 $2 \mu \mathrm{l}$ をマイクロシリン 
Table 7 Knockdown activity of SSI-116 and ethofenprox against Periplaneta americana male adults.

\begin{tabular}{lcccc}
\hline \multirow{2}{*}{ Compound } & Dose & \multicolumn{3}{c}{$\mathrm{KT}_{50 \pm \mathrm{S} . \mathrm{D} .(\mathrm{min})}$} \\
\cline { 3 - 5 } & & $18^{\circ} \mathrm{C}$ & $25^{\circ} \mathrm{C}$ & $30^{\circ} \mathrm{C}$ \\
\hline SSI-116 & $32 \mathrm{nmol}$ & $3.79 \pm 0.70$ & $512 \pm 1.79$ & $7.07 \pm 0.35$ \\
Ethofenprox & $32 \mathrm{nmol}$ & $1.90 \pm 0.17$ & $3.01 \pm 0.49$ & $3.82 \pm 1.66$ \\
\hline
\end{tabular}

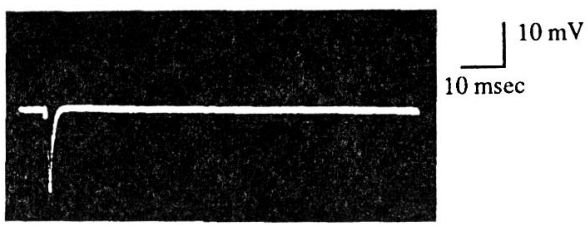

A : Unteated.

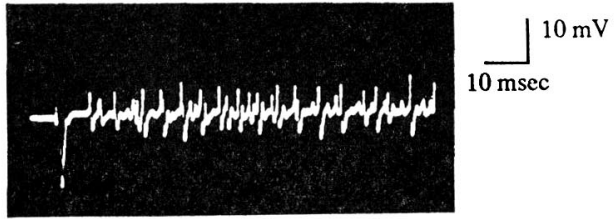

B : 30 min after treatment of SSI-116 $\left(8.0 \times 10^{-6} \mathrm{M}\right)$.

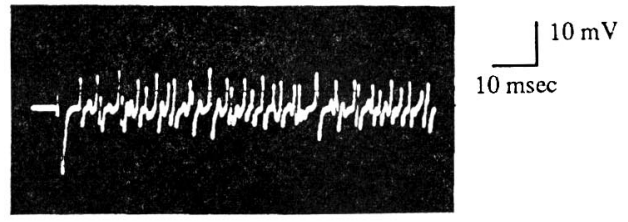

C : $30 \mathrm{~min}$ after treatment of ethofenprox $\left(8.0 \times 10^{-7} \mathrm{M}\right)$.

Fig. 3 Repetive firings induced with SSI-116 and ethofenprox in vental nerve cord of Peviplaneta americana.

ジで注入しノックダウン活性苍测定した (Table 7). SSI-116 はエトフェンプロックスより莎干低い活性で あったが，两化合物とも負の温度相関を示した。この傾 向は，多くのピレスロイドと同様であった ${ }^{11)}$.

2)ワモンゴキブリ摘出中枢神経系に対する生理活性 ワモンゴキブリ婎成虫の胸部および腹部神経節を含む 中枢神経索を用いて，細胞外電極法により，中川ら(2)の 广法に従って反復興奮誘起活性を調べた (Fig. 3). 雨化 合物とも算一刺激により, 摘出中枢神経系に対して反復 興舊を誘起したがエトフェンプロックスのほうが高かっ た.この場合もピレスロイドやDDTと同様に, 負の温 度相関を示した ${ }^{13)}$ 。また，ピレスロイドをタイプIと夕 イプIIに分類する試みがなされており ${ }^{14)}$, タイプI化 合物は, 神経生理学的効果が中毒症状において與奮性の 作用を示すのに刘して, タイプII化合物は, 中毒症状 において痼攣を示し，摘出神経に対しては抑制効果を示 すといわれている.したがって，このような分類に從え ば, SSI-116 はタイプIに相当すると考えられた。
3)アメリカザリガ二食道抱接神経環に対する生理 活性

アメリカザリガニ (Procam'arus clarkii) カ2ら摘出し た食道抱接神経環の巨大神経軸索を用いて，尾松らの方 法に彷って ${ }^{15)}$, 細胞内電極法によって膜電位を測定した

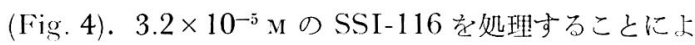
って, 脱分極性後電位の増大が認められた。样憍は ${ }^{16)}$, ピレスロイド系化合物によって誘起される反復與巂は, 脱分極性後電位の増大に起因していると指摘している. また, 西村ら ${ }^{17)}$ b，エトフェンプロックスについて同様 な現象を報告しており，SSI-116の神経生理的効果当 これらピレスロイドに類似していることが確認された。

以上のことから，SSI-116 は昆虫および甲殸類におけ る種々の生理活性において，エトフェンプロックスの生 物的等価体であることが明らかになった。

\section{3. 物理化学的性質}

1) 物性

ケイ素置換すると脂溶性が増大することが知られてい 
A

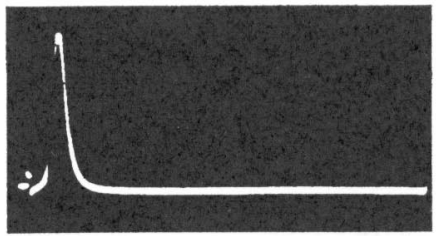

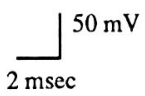

B

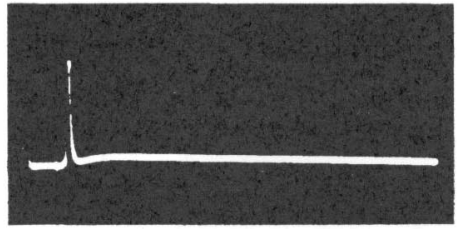

C

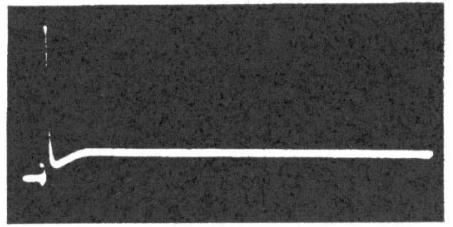

$\underset{10 \mathrm{msec}}{50 \mathrm{mV}}$

$\varlimsup_{10 \mathrm{msec}}^{50 \mathrm{mV}}$
A : Untreated.
B : $13 \mathrm{~min}$ after treatment of SSI-116 $\left(3.2 \times 10^{-5} \mathrm{M}\right)$
C : $25 \mathrm{~min}$ after treatment of SSI-116 $\left(3.2 \times 10^{-5} \mathrm{M}\right)$.

D

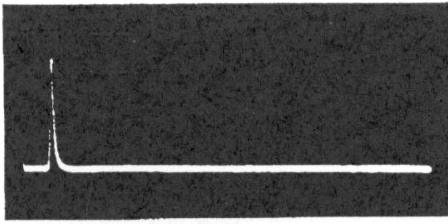

$\underset{5 \mathrm{msec}}{\mathrm{m}} 50 \mathrm{mV}$

E

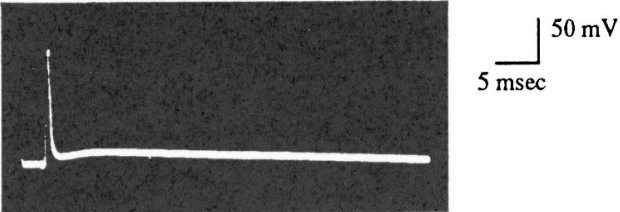

$\mathrm{F}$

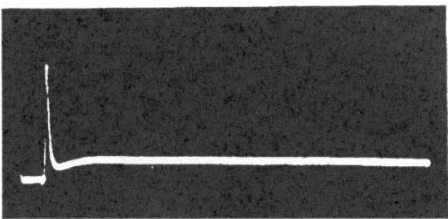

$50 \mathrm{mV}$

D : Untreated.

E : $25 \mathrm{~min}$ after treatment of ethofenprox $\left(1.0 \times 10^{-6} \mathrm{M}\right)$.

$\mathrm{F}$ : $37 \mathrm{~min}$ after treatment of ethofenprox $\left(1.0 \times 10^{-6} \mathrm{M}\right)$.

Fig. 4 Effect of SSI-116 and ethofenprox on action potential followed by single stimulus in giant axon of Procambarus clarkii.

る ${ }^{6)}$ 筆者らの測定によると，予想どおり SSI-116はエ トフェンプロックスより脂溶性が高く $\left(\log P_{\mathrm{o} / \mathrm{W}}=6.1\right)$, 水溶解度の低い $\left(25^{\circ} \mathrm{C}, 0.24 \mathrm{ppm}\right)$ 化合物であった。

2) 加水分解

新たに生じたケイ素一炭素結合は代謝されやすくなる ことが知られている6)。そこでをず，緩衝溶液中におけ る安定性を $50^{\circ} \mathrm{C}$ の条件で 14 日後に調べたところ，両 化合物ともほとんど分解されなかった。しいてあげれ ば，pH 4 でSSI-116 は 4\% ほど分解され，酸性触媒 による分解が推定された。

3) 光 分 解

次に, 約 270 400 nm の波長を有する紫外線ランプ （東芝 FL20SE）を用いて，光分解を行なった（Fig. 5). 両化合物之も暗黒条件下では分解は認められなかった。 しかし，UVライト照射条件下ではSSI-116 は分解が 速く, 残存率は 14 日後に $14 \%$ であった（エトフェンプ ロックスは $75 \%$ 残存). SSI-116 の分解物 (I V VI) の 構造㧍よび分解速度を調べ，分解経路を推定した(Fig. $6)^{18)}$. 大沼ら ${ }^{19)}$ が報告しているェトフェンプロックス の光分解経路との大きな違いは, 新たに形成したケイ素一 炭素結合の炭素原子が酸化される経路が增光たことであ った．光分解に対して両化合物に大きな違いが認められ

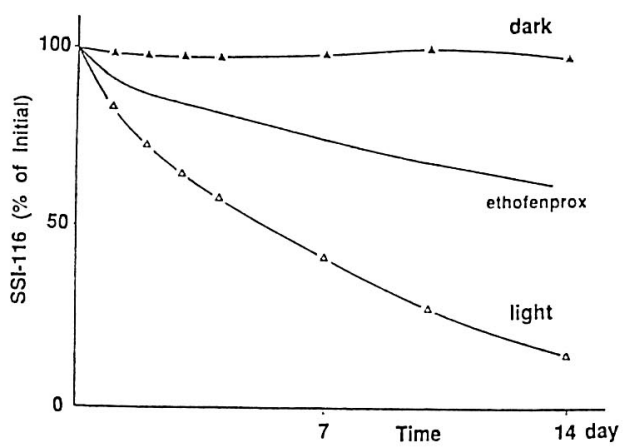

Fig. 5 Degradation of SSI-116 under UV-light or dark condition.

たことより，生体内での代謝分解経路㧍よび速度にも大 きな違いが生じる可能性が指摘された。

\section{4. 魚 毒 性}

SSI-116 のコイに対する毒性を調べたところ， 562 ppmでる 48 時間後ではょったく毒性は镜察できなか った. エトフェンプロックスの公表值は $5.0 \mathrm{ppm}$ であ り，両化合物の間にかなりの違いが認められた，その原 因について調べるため， $5.0 \mathrm{ppm}$ 濃度における暴露実 験を行ない，コイの血液および脳での化合物の濃度を経 


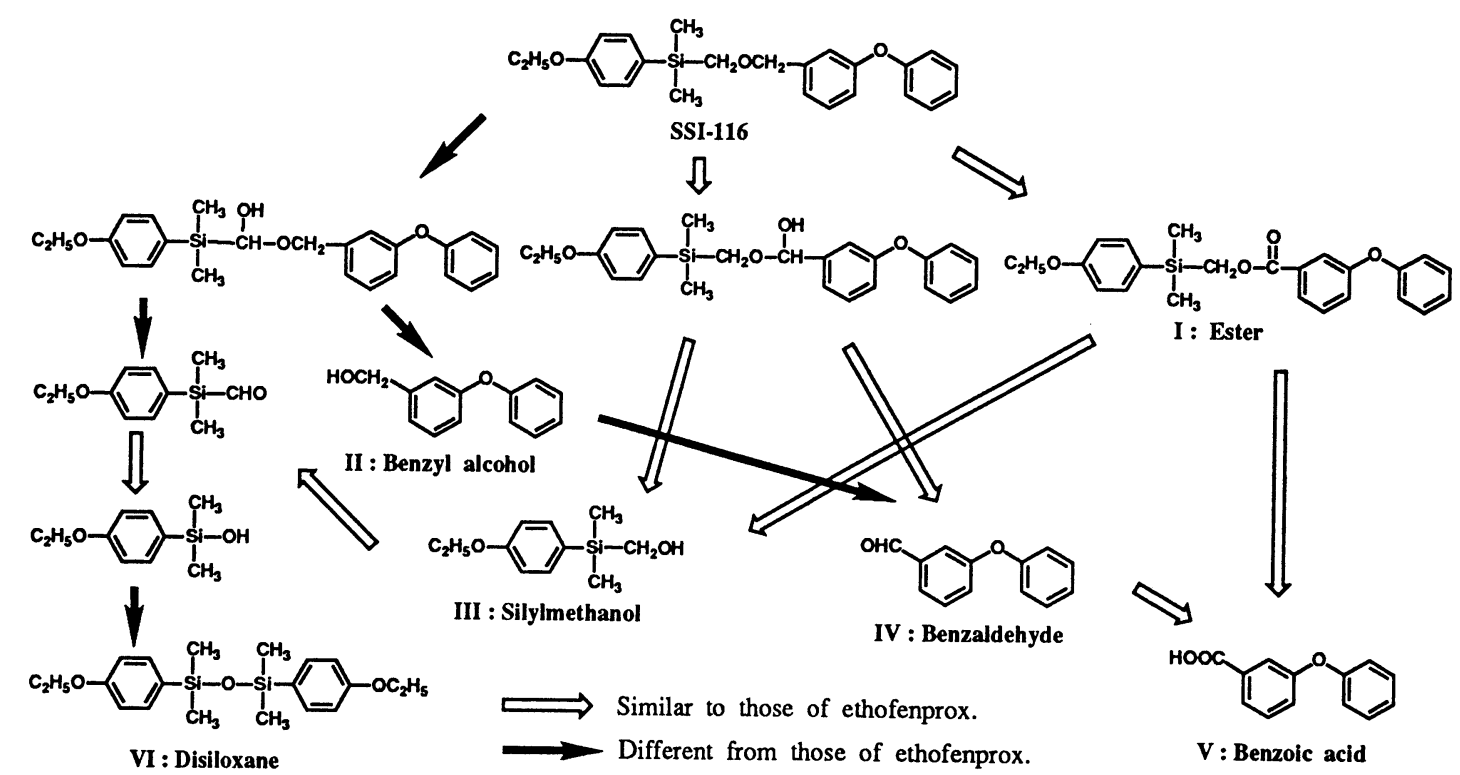

Fig. 6 Photodegradation pathways of SSI-116.

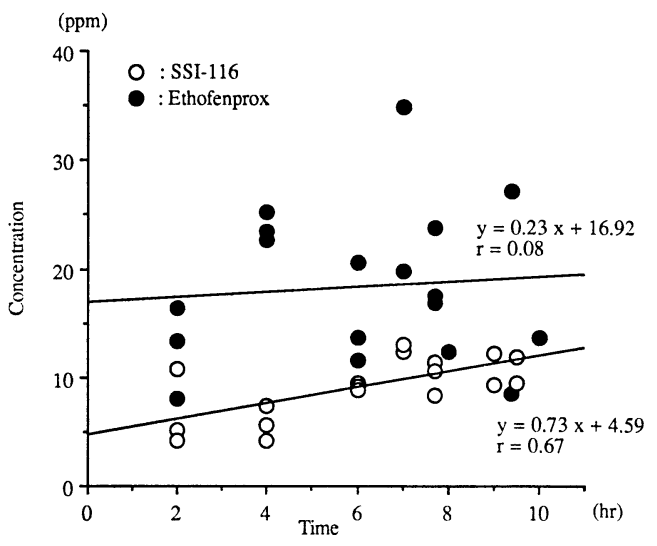

Fig. 7 Concentration of SSI-116 and ethofenprox in blood.

時的に測定した (Fig. 7，8). 相関係数はやや小さいもの の, 両化合物とも脳中濃度と暴露時間に相関が認められ た. 魚類においても神経が両化合物の生理活性発現の主 要な作用部位であると仮定すると，この約 4 倍の脳中へ の蓄積速度の差が両化合物の魚毒性に大きな差をもたら した重要な要因と考えられた.

\section{SSI-116 の製椷学的検討}

SSI-116 の生物活性および生理作用などを検討した

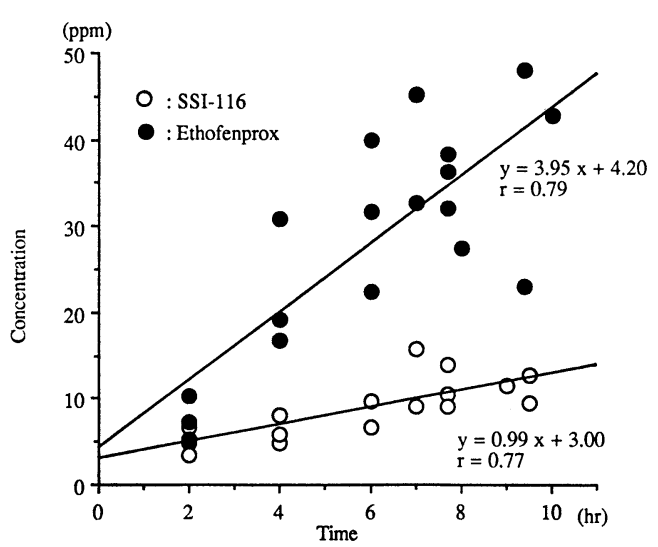

Fig. 8 Concentration of SSI-116 and ethofenprox in brain.

結果, ピレスロイド様殺虫活性を有し, 水田害虫に卓効 を示す低魚毒性の化合物であることが明らかとなった。

しかし，SSI-116 はエトフェンプロックスに比へ， やや殺虫活性が劣ること, 光分解が速いことなどもわか った．そこで，水田用殺虫剤として実用化をするため に，製剤化による活性向上の検討を行なった．製剤の 形態として，水田用殺虫剂に最も広く用いられている DL 粉剤を採用した. 多くの農薬がキャリヤー中で分解 することが知られているので，まず DL 粉剂に使用す 
Table 8 Influence of carrier of SSI-116 0.5\% DL dust formation on deposit and insecticidal activity against $N$. cincticeps.

\begin{tabular}{lcccccc}
\hline & \multicolumn{6}{c}{ Sample } \\
\hline & $\begin{array}{c}\text { Calcium } \\
\text { carbonate }\end{array}$ & Clay & \multicolumn{4}{c}{$\begin{array}{c}\text { Mixed carrier } \\
\text { (calcium carbonate: clay) }\end{array}$} \\
\hline & No. 14 & No. 11 & No. $19(3: 1)$ & No. $21(1: 1)$ & No. $23(1: 3)$ & Trebon \\
\hline Mortality (\%) (at 24 hr) & 75 & 39 & 70 & 86 & 65 & 78 \\
\hline Deposit $(\mu \mathrm{g} /$ plant) & 36.6 & 23.0 & 33.5 & 41.7 & 32.0 & 26.6 \\
\hline
\end{tabular}

るキャリヤーおよびホワイトカーボン中における SSI116 の安定性を調べた。 その結果，表面酸性度 $(\mathrm{p} K \mathrm{a})$ が大きく関与しており $\mathrm{pKa}$ の值が小さいほど分解され やすいことが明らかとなった. 次に，DL 粉剤にドリフ 卜防止剤として添加される凝集剤の安定化効果を調べた ところ，ソルポール類が高い効果を示した．以上の安定 性試験の結果を考虑して，20 種以上の DL 粉剤を検討 した $\left(\right.$ Table 8) ${ }^{20)}$. その結果，No. 21 の製剤がトレボ ンより高い殺虫活性を示すことがわかった．それは稲体 への付着量がトレボン製剤より 1.5 倍ほど多いためであ った．さらにこの製剤の浮遊性指数は 9.8 であり，ドリ フトは少なく，围場での使用に問題がなかった。このよ うに，SSI-116 とエトフェンプロックスの本質的な殺 虫活性の差を，製剤化により同等以上に改善することが できたので，この剤を用いて畕場試験を行なった。

\section{SSI-116 の畨場試験}

水田害虫用には $0.5 \%$ あるいは $1 \% \mathrm{DL}$ 粉剤を，畑 地用および果樹用には $20 \%$ の乳剂および水和剂を用い て, 社内外の围場試験を実施した (Table 9). その結果, SSI-116 はとくに水田の重要害虫であるッマグロヨコ バイ，ウンカ類およびイネミズゾウムシに $0.5 \%$ DL 粉 剤でも高い効果を示すことがわかった，また，イネミズ ゾウムシに関しては育苗箱処理においても，効果が認め られた ${ }^{21)}$. しかし，畑地および果樹では 2〜3 種の害虫 を除き，あまり高い効果は認められなかった。以上， SSI-116 の水田用害虫防除剂としての実用性を確認す ることができた。

\section{おわりに}

今回, 農薬の分野におけるケイ素置換法の有用性につ いて検討した.エトフェンプロックスに適用することに より，低魚毒性な新規含ケイ素ピレスロイド剂，SSI116 を見いだした，SSI-116 は，害虫に対する殺虫活
Table 9 Insecticidal efficacy of SSI-116 at field test.

\begin{tabular}{llc}
\hline \multicolumn{1}{c}{ Test species } & Rank $^{\mathrm{a})}$ \\
\hline \multirow{4}{*}{ Paddy } & Lincticeps & $\mathrm{A}$ \\
& L. striatellus & $\mathrm{A}$ \\
& N. lugens & $\mathrm{A}$ \\
& S. furcifera & $\mathrm{A}$ \\
& L. oryzophilus & $\mathrm{A}$ \\
& O. oryzae & $\mathrm{B}$ \\
& C. modinalis & $\mathrm{B}$ \\
C. supprissa'is & $\mathrm{B}$ \\
\hline \multirow{4}{*}{ Upland } & P. vingoniella & $\mathrm{A}$ \\
& C. niponensis & $\mathrm{A}$ \\
& P. rapae crucivora & $\mathrm{B}$
\end{tabular}

a) A and B mean SSI-116 is superior and similar to conventional insecticides, respectively.

性およびノックダウン活性, 昆虫類および甲殻類に対す る電気生理学的活性においては, 効果は劣るものの, エ トフェンプロックスの生物学的等価体であると結論され た.しかし，魚毒性においては，当初の期待どおりに， かなり軽減されていた。この原因については，まだ明ら かではないが，一因しして，新たに形成したケイ素-炭 素結合の分解によると考えている. SSI-116 は，围場 試験においても水田害虫に優れた効果を示し, 急性経口 毒性試験および変異原性試験なども問題がなかった。し たがって，農薬の分野においてもケイ素置換法の有用性 が明らかとなった。

最近，へキスト社も，MTI-800のケイ素置換体であ る HOE-498 の開発を検討しており ${ }^{22)}$ ，ケイ素置換す ることによる予想以上の生物学的挙動の変化を見いだし ている.

このように, 既存の農薬をケイ素置換する試みは, 新 規な剂の開発に有効だと思われるが，まだ始まったばか りであり，今後さらに発展することを期待する。 
本研究の機会を与えられ, 種々ご便宜をいただいた塩 野義製薬(株)油日ラボラトリーズ長・武田禮二博士, 前 同ラボラトリーズ長・林 幸之博士に梁く感謝いたしま す. 本研究の遂行にあたり梁いご理解を示され，ご指導 いただいた同ラボラトリーズ・石黒丈男博士, 武内康義 博士, 早瀬善男博士, 高橋俊夫博士, 安藤 踇博士, 大 羽克明博士, 森 聖博士に, また数々のご協力をいた だいた同ラボラトリーズ・照岡 篤博士, 水谷 章博 士, 片山慈敏氏, 中島一人氏, 藤田裕輔氏, 宮園 稔氏, 西田邦好氏の方々に深く感謝いたします。

最後に，本研究の発表を許可していただいた塩野義製 薬(株)に衣心より謝意を表します.

\section{引用文 献}

1) M. S. Schechter, N. Green \& F. B. LaForge: J. Am. Chem. Soc. 71, 1517 (1949)

2) 上田 実：植物防疫 36, 64 (1982)

3) H. Hamana \& A. Hosoda: Appl. Entomol. Zool. 18, 475 (1983)

4) 都築 仁，五十川是治：植物防疫 30，34 (1976)

5) K. Nakatani, T. Inoue, S. Numata, K. Oda, T. Udagawa \& M. Gohbara: Abstr.; 5th Int. Congr. Pestic. Chem., Kyoto, 1a-9, 1982

6) U. Wannagat: "Biochemistry of Silicon and Related Problems," ed. by G. Bendz \& I. Lindquist, Plenum Press, New York/London, 1978

7) R. J. Fessenden \& J. S. Fessenden: Adv. Organomet. Chem. 18, 275 (1980)

8) R. J. Fessenden \& M. D. Coon: J. Med. Chcm. 9, $262(1966)$

9) M. Eliott \& N. F. Janes: Chem. Soc. Rev. 7, 473 (1978)

10) 西内康浩, 岩村 肇, 浅野和也：生態化学 8, 13 (1985)
11) G. G. Briggs, M. Elliott, A. Farnham \& N. F. James: Pestic. Sci. 5, 643 (1974)

12) S. Nakagawa, N. Okajima, T. Kitahara, K. Nishimura, T. Fujita \& M. Nakajima: Pestic. Biochem. Physiol. 17, 243 (1982)

13) D. W. Gammon: Pestic. Sci. 9, 95 (1978)

14) D. W. Gammon, M. A. Brown \& J. E. Casida: Pestic. Biochem. Physiol. 15, 181 (1981)

15) M. Omatsu, K. Nishimura \& T. Fujita: Pestic. Biochem. Physiol. 24, 192 (1985)

16) T. Narahashi: Comp. Biochem. Physiol. 72C, 411 (1982)

17) K. Nishimura, T. Kobayashi \& T. Fujita: Pestic. Biochem. Physiol. 25, 387 (1986)

18) 照岡 篤, 斎藤裕之, 大塚俊一, 安藤 膂, 早瀬 善男, 林 幸之: 日本農薬学会第 14 回大会講演 要旨集, p. 89, 1989

19) 大沼一富, 今井孝光, 荒井 優, 小田研吾, 友田 健一：日本農薬学会第 14 回大会講演要旨集, $p$. 131,1987

20) 照岡 篤, 井場や之子, 藤田祐輔, 中島一人, 大 塚俊一, 安藤 跤: 日本農薬学会第 13 回大会講 演要旨集, p. 134,1988

21）藤田祐輔, 水谷 章, 川瀬忠徳, 大羽克明：関西 病虫害研究会報 29，37 (1987)

22) H. Schubert, G. Salbeck, W. Knauf, R. Schaub \& A. Waltersdorfer: 日本農薬学会第 14 回大会 講演要旨集，p. 55, 1989 